\title{
Variability of Microclimate Daily Dynamic in Small Island
}

\author{
Christophil S. Medellu
}

Department of Physics, Manado State University. Indonesia.

E-mail: chrismedellu@yahoo.co.id

\begin{abstract}
Microclimate variables are very sensitive to changes in environmental conditions. Microclimate variables change temporally following changes in solar radiation and vary spatially due to differences in ecological features. Micro climate parameters are the quantity of microclimate variables which characterize ecosystems. Micro climate parameters are used in monitoring the condition of natural resources and environmental. Small island ecosystems are easily disturbed by natural factors such as storms, waves and currents, droughts, floods and surface erosion etc. Small island ecosystems also experience degradation and even sudden changes due to resource use such as forest reshaping, groundwater extraction, expansion of residential areas etc. Characterization and monitoring of micro-climates of small island ecosystems are needed for resource and environmental management. Spatial and temporal variations of microclimate in residential locations, forests and coastal waters can characterize ecosystems and are used to monitor changes in environmental conditions. Climate data is needed as a reference for environmentally
\end{abstract}

friendly spatial use such as reforestation, cultivation of plants in the yard. This article discusses the results of research on the diversity of air temperature and humidity in three small islands in the Sangihe District. In each village area, four research sites were selected, namely in residential areas, forested beaches, coastal waters in front of settlements, and coastal waters in front of forested beaches. At each location, measurements are made at six points in the vertical direction. The results showed that micro-climate parameters differed significantly between the location of settlements and forested beaches.

Keywords- micro-climate, dynamics, settlements, forests, coastal waters.

\section{INTRODUCTION}

Life on a small is land has more severe challenges than in the large land area. Hurricanes, abrasions, droughts and lack of water are serious problems faced by people on small is lands. The use of land with limited size causes pressure to reduce the quality and usefulness of land as shown in Figure-1:

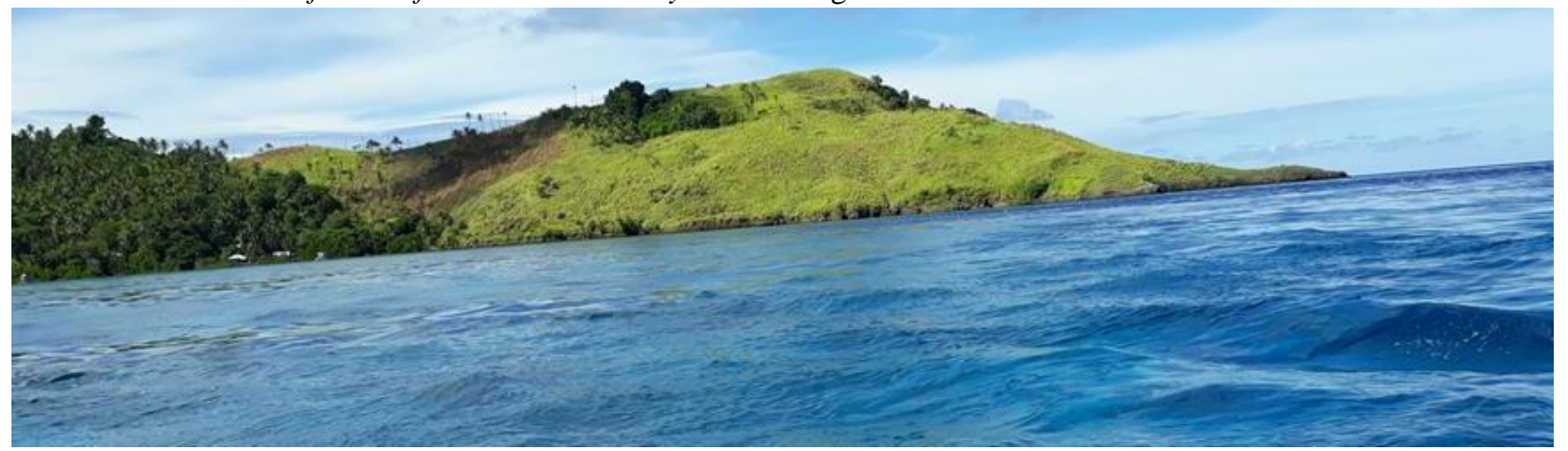

Fig.1: Unproductive land on Kahakitang Island, Sangihe Regency

The land conditions as shown in Figure-1 are a series of problems: environmentally unfriendly land use - increased surface erosion - top soil quality degradation and decreased land quality, the survey conducted in 2016-2017 showed that in Tatoareng Sub-district, weeds can reach $28 \%$. Land degradation in the Tatoareng area has the potential to increase due to population growth and reduced land for plantations and settlements. Small island management must be carried out comprehensively and systemically by analyzing the influence of natural and human factors on natural and environmental resources. Management of small island resources must be based on a comprehensive and 
systematic analysis according to the characteristics of small islands (Mercer et al., 2007). The components studied include biophysical, socio-cultural and economic components as a whole. Existing condition analysis is needed to predict global impacts such as climate change (van Aalst, 2006) and sea level rise (Rodolfo and Siringan, 2006). Pelling and Uitto (2001) suggest that the management of small islands needs to examine the interaction between global pressure and local dynamics that contribute to increasing environmental vulnerability. Mercer et al., (2007), suggested that the assessment of resource and risk vulnerability is a focus of resource management. Mapping critical and vulnerable areas is carried out as a focus of ecosystem studies which include biophysical, socio-cultural and economic elements (Bengen et al. 2003; White et al, 2006). Pregiwati et al. (2015) suggested that ecosystem elements became the criteria in determining protection areas in the sea area. Mapping and geographic information systems are seen as comprehensive tools in presenting ecosystem conditions and their management (Guinau et al, 2005; Corbett et al., 2006).

Microclimate is defined as the climate condition of the localized area as a different zone with surrounding environment (Chen et al. 1999; Medellu, 2012). Microclimate variables characterize ecosystem conditions. Changes in the magnitude of micro-climate parameters indicate changes in ecosystems and the environment (Medellu, 2012, 2013; Medellu and Tulandi, 2018). Microclimate variables were studied by experts are the intensity of solar radiation, air temperature and air humidity (Hennenberget al., 2008; Medellu, 2012; de Lima et al. 2013, Medellu and Tulandi, 2018). The microclimate variables change temporally following the changes of solar radiation intensity (Newmark. 2001; Medellu, 2012). Microclimate variables varies spatially due to local conditions or the earth surface (Medellu, 2012, de Paula $e t$ al, 2016, Medellu and Tulandi, 2018). Spatial variation of forest microclimate influenced by the structure of the forest such as variation of tree high, the patch and the gap in the forest (Pinto et al., 2010; Zulkiflee and Blackburn, 2010). The spatial variation of microclimate on small islands is very high between forest areas and densely populated residential areas. Changes in land conditions such as deforestation and environmental change are very significant causing changes in microclimate (Godefroid et al., 2006; Berger et al. 2008, Gradstein, 2008). Micro-climate parameters are quantitative quantities that characterize ecosystem and environmental conditions (Medellu, 2013; Medellu and Tulandi, 2018). Microclimate parameters often used by experts were: the maximum difference of edge interior, the depth of edge effect, and the maximum edge. This parameter is a microclimate variable magnitude based on the measurement and analysis of data in the horizontal direction, for example from the edge of the forest to the inside of the forest. The depth of edge effects canindicate the fragmentation or gaps in the forest or changes in the structure of the forest (Harper et al. 2005, Medelluet al, 2012; Magnagoet al. 2015). Edge gradient associated with the flow of thermal energy between the environment and forest ecosystems (Heithecker and Halpern, 2007; Medellu, 2013; Chatterjea, 2014).

Measurement, analysis and modeling of microclimate daily data in vertical directions, can adopt analysis and modeling data in the horizontal direction. Analysis and modeling of daily data in the vertical direction describe the thermal interactions on the surface of the land and on the surface of the water. Referring to the pattern of daily changes in the horizontal direction, the micro-climate parameters used can be adopted for vertical profile analysis. The vertical profile of the daily changes of microclimate variable at several locations on small islands is very important as a reference for the use of natural resources. This article describes the micro-climate parameters in twelve measurement positions on three islands in the village area in Tatoareng District, Sangihe Regency.For each village area, measurements were carried out in four locations. Two locations are located on land, namely at the center of the settlement and in the forested beach of same the village area. The other two locations are in the coastal waters, at $60 \mathrm{~m}$ to $70 \mathrm{~m}$ away from the coastline. One position is located in front of the settlement and one position is located in front of a wooded beach. The purpose of this measurement is to analyze differences in the microclimate conditions of residential areas and forests, where forest areas are a source of drinking water for communities in residential areas. The parameters of micro-climate data are also complemented by examples of temporal changes graphs of air temperature at three locations with different ecological features. Utilization of research results includes: (1) reference to the cultivation of vegetables and spices in the yard to prevent the conversion of forest functions as a source of water, (2) to become a reference for comfort analysis related to the development of this region as the main tourism destination of Sangihe Regency 3) becomes a reference for determining reforestation areas that have the potential to increase infiltration and control of surface erosion. 


\section{RESEARCH METHOD}

The study was conducted on three adjacent islands in the area of TatoarengSubdistrict, Sangihe Regency, North Sulawesi Province. Tatoaremng sub-district consists of small islands with a density reaching 42 people/ha (Sangihe in numbers, 2013). Population density has slowed grow but is projected to increase sharply due to the increase in tourist arrivals in several tourist attractions in the region. The location of measurements is carried out in three villages, each in two positions with different ecological features. The first village to be measured was the village of Para Lele, located on the island of Para. Measurements at the first location were carried out at residential sites and forested beache located west of the residential area. Measurements are also carried out above sea level, each at $60 \mathrm{~m}-70 \mathrm{~m}$ in front of the coastline at residential locations and forested beaches. The second location is Mahengetang village on Mahengetang island. Measurements were made in residential areas and forest areas located in the eastern part of the settlement. Measurements in coastal waters as done on the island of Para. The third location is the Behongang village area, located on Kahakitang island. Measurements were made in the residential center of Behongang Village, and the forested beach of Kundaha sub-village. Measurements in coastal waters are the same as in Para and Mahengetang island. The reason for choosing two measurement positions, namely residential and plantation areas is to produce data on the existing condition of the ecosystem as a reference in resource use and environmental management, especially related to the guarantee of water availability. The measurement location, which is a forested beach adjacent to the settlement, is a water source used by the community, especially during the dry season. Measurements in each position are carried out for one day with an hourly measurement interval. Measurements in two positions on land in the same village area are carried out simultaneously. Measurements in two locations on coastal waters within the same village area were carried out simultaneously. Two measurement locations in the Behongang village area are shown in Figure-2 and Figure-3. Kundaha village children become suppliers of fresh water for the community in the parent village of Behongang.

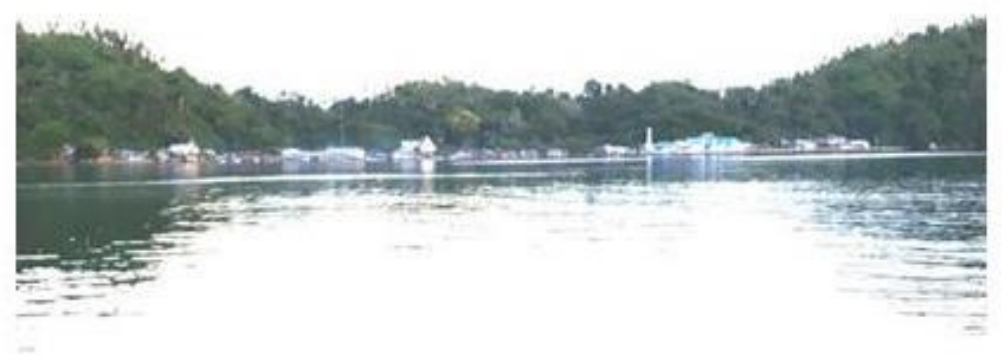

Figure-2. Behongang village, Kahakitang island

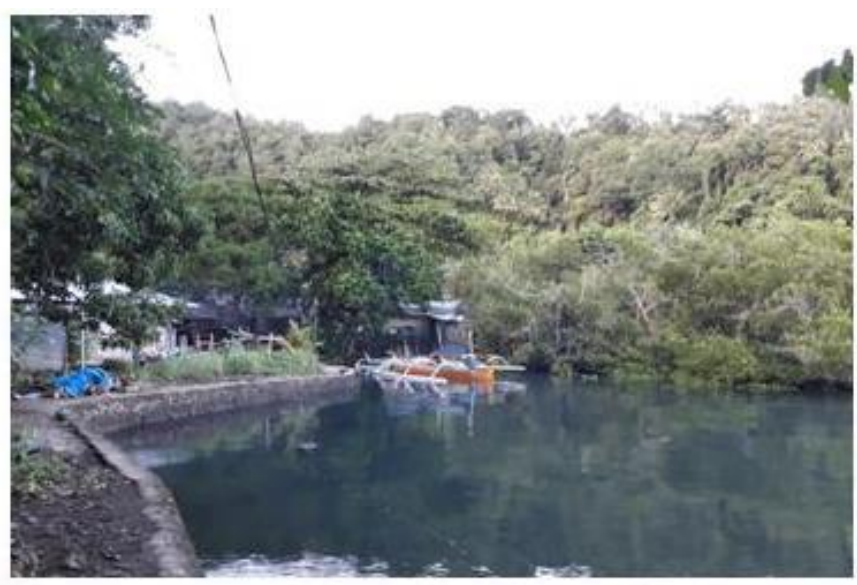

Figure-3. Kundaha, sub village of Behongang 
Micro climate variables measured and analyzed are air temperature and air humidity in the vertical direction at each measurement location. The measurement points for each vertical transect use logarithmic distance to the boundary plane, namely: $0,1 \mathrm{~m}, 2 \mathrm{~m}, 4 \mathrm{~m}, 8 \mathrm{~m}$ and $16 \mathrm{~m}$ The logarithmic measurement method is based on the assumption that changes in thermal energy per unit distance are greater near the medium boundary (Medellu, 2012, Medellu and Tulandi, 2018). Adaptation of measurement methods and analysis of measurement data in the horizontal direction for measurement data in the vertical direction is based on the assumption of energy diffusion between the layers of the medium (air, soil and water), and thermal interactions between the air-water and air-ground boundaries.The stages of data analysis and modeling to produce temporal and spatial functions and micro-climate parameters are as follows (Medellu, 2013; Medellu and Tulandi, 2018)

1. Arrange data in a data matrix, based on time and position, for example for temperature: $\mathrm{T}(\mathrm{y}, \mathrm{t})$, where $\mathrm{x}$ is the distance to the boundary plane and $t$ is time. The data matrix is adjusted to the data input format of the micro climate data analysis and modeling software

2. Determine the temporal function as a periodic function or Fourier function. Temporal function modeling produces output in the form of maximum and minimum quantities, and the time to reach that quantity.

3. Synchronizsation of data between positions, by inputting the difference of measurement time data between positions, into temporal functions. This procedure is carried out as a requirement for spatial function modeling, where the data used must have the same time base

4. Modeling spatial functions using exponential function models. Modeling assumes greater absorption of energy and changes in variable microclimate occurring near the boundary plane. Modeling of spacial function will produce parameters: maximum gradient, highest daily difference between vertical measurement points, and depth of edge effects (the farthest distance of the microclimate magnitude becomes constant, time for achieving thermal equilibrium (gradient has zero value)

5. Comparing the magnitudes of micro climate parameters and vertical profiles of air temperatures between locations and measurement positions

\section{RESEARCH RESULTS AND DISCUSSION}

Quantity of micro climate parameters: variable air temperature above ground

Measurements carried out in normal weather conditions where light rain occurs three to four times a week, producing micro climate parameter data as shown in Table1. Codes P1, M1, and B1 are measurement positions in the center of the settlement and above the sea in front of settlements in the villages of Para, Mahengetang and Behongang. Code P2, M2, and B2 are measurement positions on wooded beaches and above the sea in front of forested beaches in the villages of Para, Mahengetang and Behongang. Table-1 presents the quantity of micro-climate parameters and local time for achieving this quantity. The maximum air temperature occurs at a distance of 0 to $20 \mathrm{~cm}$ above the land surface. The air temperature during the day including the maximum value, is quite significant different between the location of the settlement and the forested beach. The maximum temperature difference in settlements with adjacent forested beach ranges from $5.5^{\circ} \mathrm{C}$ to $7.72^{\circ} \mathrm{C}$. This variation is caused by differences in ecological conditions such as land material (sand or soil), the presence or absence of land cover, the structure and the dense of canopy etc. The earlier maximum temperature is reached in residential locations compared to the location of the forested beach adjacent to the settlement. The highest maximum temperature difference occurred between Behongan village and Kundaha sub-village. Variation in the difference in time to reached the maximum temperature between location of the settlement and the forest area in the three village areas ranged from 32 minutes to 55 minutes.

Table.1: The quantity and time of achieving the quantity of micro climate parameters at the research location

\begin{tabular}{|c|c|c|c|c|c|c|c|c|c|c|c|c|c|}
\hline \multicolumn{2}{|c|}{ Microclimate } & \multicolumn{12}{|c|}{ Quantity of parameter acoording to location and position } \\
\hline \multirow{2}{*}{ Variable } & \multirow{2}{*}{ Parameter } & \multicolumn{4}{|c|}{ Para village } & \multicolumn{4}{|c|}{ Mantehagevillage } & \multicolumn{4}{|c|}{ Behogangvillage } \\
\hline & & P1 & time & $\mathrm{P} 2$ & time & M1 & time & M2 & time & B1 & time & B2 & time \\
\hline \multirow{3}{*}{$\begin{array}{l}\text { Air } \\
\text { temperatureover } \\
\text { the land }\end{array}$} & $\begin{array}{l}\text { maximum( } \\
\left.{ }^{\circ} \mathrm{C}\right)\end{array}$ & 39.9 & $13: 18$ & 34.2 & $13: 58$ & 39.7 & $13: 22$ & 34.2 & $13: 54$ & 39.92 & 13:05 & 32.2 & $14: 00$ \\
\hline & $\begin{array}{l}\text { minimum } \\
\left.{ }^{\circ} \mathrm{C}\right)\end{array}$ & 27.4 & $02: 55$ & 25.2 & $02: 52$ & 27.3 & $02: 48$ & 25.0 & $02: 48$ & 27.3 & $02: 44$ & 24.8 & $02: 42$ \\
\hline & Maximum & 0.2 & $10: 56$ & 0.08 & $11: 22$ & 0.18 & $11: 22$ & 0.12 & $10: 38$ & 0.19 & $11: 20$ & 0.03 & $11: 24$ \\
\hline
\end{tabular}




\begin{tabular}{|c|c|c|c|c|c|c|c|c|c|c|c|c|c|}
\hline & $\begin{array}{l}\text { gradient } \\
\left.{ }^{\circ} \mathrm{C} / \mathrm{m}\right)\end{array}$ & & & & & & & & & & & & \\
\hline & $\begin{array}{l}\text { Thermal } \\
\text { equilibrium of } \\
\text { Air-soil }\end{array}$ & & $19: 32$ & & $19: 42$ & & $19: 24$ & & $19: 26$ & & $19: 44$ & & $19: 22$ \\
\hline \multirow{4}{*}{$\begin{array}{l}\text { Air temperature } \\
\text { over the sea } \\
\text { surface }\end{array}$} & $\begin{array}{l}\text { maximum( } \\
\left.{ }^{\circ} \mathrm{C}\right)\end{array}$ & 40.1 & $12: 58$ & 39.8 & $13: 16$ & 39.9 & $12: 56$ & 39.70 & $13: 22$ & 39.8 & $12: 55$ & 39.2 & $13: 16$ \\
\hline & $\begin{array}{l}\text { minimum } \quad( \\
\left.{ }^{\circ} \mathrm{C}\right)\end{array}$ & 27.8 & $3: 14$ & 26.7 & $2: 52$ & 27.6 & $3: 48$ & 26.8 & 3:00 & 27.7 & $2: 44$ & 25.8 & $2: 42$ \\
\hline & $\begin{array}{l}\text { Maximum } \\
\text { gradient } \\
\left.{ }^{\circ} \mathrm{C} / \mathrm{m}\right)\end{array}$ & 0.22 & 10:02 & 0.1 & $10: 40$ & 0.2 & 11:02 & 0.12 & 10:03 & 0.19 & $10: 28$ & 0.03 & $11: 24$ \\
\hline & $\begin{array}{l}\text { Thermal } \\
\text { equilibrium of } \\
\text { Air-Water }\end{array}$ & & $18: 54$ & & $18: 22$ & & $18: 48$ & & $18: 28$ & & $18: 52$ & & $18: 20$ \\
\hline \multirow{3}{*}{$\begin{array}{l}\text { Humiity over } \\
\text { the land surface }\end{array}$} & $\operatorname{maximum}\left({ }^{\circ}\right)$ & 88.4 & $02: 00$ & 90.2 & $01: 58$ & 88.5 & $02: 10$ & 89.4 & $02: 00$ & 88.8 & $02: 10$ & 93.8 & $01: 50$ \\
\hline & minimum $\left({ }^{\%}\right)$ & 82.8 & $11: 40$ & 84.8 & $11: 54$ & 83.0 & $11: 35$ & 84.5 & $11: 40$ & 83.2 & $11: 42$ & 85.5 & $11: 48$ \\
\hline & $\begin{array}{l}\text { Maximum } \\
\text { gradient } \\
\% / \mathrm{m})\end{array}$ & 0.008 & $13: 20$ & 0.008 & 13:06 & 0.008 & $13: 15$ & 0.008 & $13: 40$ & 0.008 & $13: 24$ & 0.008 & $13: 55$ \\
\hline
\end{tabular}

Variations in the time to reach the maximum temperature are influenced by the reception and absorption of solar radiation energy, the conditions of land material, land cover, water on the surface and other ecological features. At the surfaces that are faster to heat (eg dry surface), the air temperature will increase faster than the wet surface that absorbs a lot of radiation energy but slowly becomes hot.

The minimum daily air temperature at a residential location is relatively higher than the minimum temperature in a forested location. The minimum air temperature in residential locations varies between $27.3^{\circ} \mathrm{C}$ to $27.4^{\circ} \mathrm{C}$, while in forested locations range from $24.8^{\circ} \mathrm{C}$ to $25.2^{\circ} \mathrm{C}$. The minimum temperature difference between residential locations and forested locations ranges from $2.2^{\circ} \mathrm{C}$ to $2.5^{\circ} \mathrm{C}$. The time to reach the minimum air temperature between residential locations and forested areas did not differ significantly. The maximum - minimum air temperature difference at the six measurement sites shows that the residential area fluctuates more $\left(12.4^{\circ} \mathrm{C}\right.$ to $\left.12.62^{\circ} \mathrm{C}\right)$ compared to the forested area $\left(7.4^{\circ} \mathrm{C}\right.$ to $\left.9.2^{\circ} \mathrm{C}\right)$. Large temperature fluctuations in residential locations are caused by more full acceptance of solar energy, as well as reflection of radiation energy such as zinc roofs, absorption and reemition of solar energy by land surface, influence of thermal emissions by the sea, community activities such as cooking, and thermal energy emitted by the body. The high temperature difference between the location of the settlement and the forested beach, shows that deforestation for settlement or secondary crops can cause an increase in temperature in a wider area.
The maximum gradient of air temperature near the surface in residential locations varies from $0.18^{\circ} \mathrm{C} / \mathrm{m}$ to $0.2^{\circ} \mathrm{C} / \mathrm{m}$, while in the forest area varies between $0.03^{\circ} \mathrm{C} / \mathrm{m}$ to $0.18^{\circ} \mathrm{C} / \mathrm{m}$. Based on the results of temporal air temperature analysis and modeling, the smallest maximum gradient is found in Kundahasub-village.The maximumminimum difference in daily air temperature in Kundala is also lower than the air temperature in other locations. In Kundaha there are two schools and six teacher houses. In the front, mangroves grow with a width of 40 to 55 meters with a fairly tight canopy.Land in the sub-village of Kundaha is drained by surface water, which originates from springs that appear at the foot of a forested hillside. This ecological feature causes the air temperature in Kundaha sub-village to be lower and more stable throughout the day. The water in the village of Kundaha is partly channeled to the main village of Behongang.Air-ground thermal equilibrium is relatively the same between locations, occurring around 17:30. This thermal equilibrium is characterized by the gradient value of air temperature at the surface of the land is zero. This means that there is no thermal energy flow between the air and the ground surface. Thermal equilibrium between air and soil in forested beach locations lasts longer than in settlements. At the settlement location, the air temperature starts to increase earlier and becomes higher than the soil temperature at around 05:00. On the location of forested beaches, an increase of air temperature occurs around 6:00. Increasing of air temperature at residential locations is also influenced by community activities such as cooking. This thermal 
equilibrium becomes important information in controlling comfort and in cultivating plants in the yard

Quantity of micro climate parameters: variable temperature of air above sea surface

Variable of air temperature above sea surface is measured in tidal areas with a distance of $60 \mathrm{~m}$ to $70 \mathrm{~m}$, from the coastline. Temperatures above the water level in the six study sites had the same vertical profile. In the morning until around 10 o'clock, the air temperature near the sea surface mixes with the temperature in the upper layer. After 1 o'clock until around 3:20, the air temperature near the sea surface is higher than the air temperature. The temperature of the air above the sea surface reaches a maximum quantity around 12:56 to 13:22. The temperature of the sea water in front of the settlement location is slightly higher than the air temperature in front of the forested beach. The highest maximum air temperature difference was obtained from the results of air temperature measurements and modeling in Behongang village andKundahasub-village, namely $0.6^{\circ} \mathrm{C}$. This difference can be thought to be caused by the supply of fresh water to the tidal area that occurs in coastal waters in front the Kundaha sub village. Difference in maximum-minimum air temperature in each location varies between $12.4^{\circ} \mathrm{C}$ to $13.4^{\circ} \mathrm{C}$. Difference in maximum-minimum of air temperature above sea level is smaller than the air temperature above the land surface. This is influenced by the receiving ption and absorption of solar energy by sea water, the movement of water masses (vertical and horizontal) that emit thermal energy into the air. Sea water stores more heat energy and slowly emits it into the air after reaching the thermal emission limit temperature. Table 1 shows that the minimum air temperature above sea level is higher than above the land surface.

The interesting thing from the results of measurement and modeling of data, is the difference in the minimum daily air temperature between the location in front of the settlement and the location in front of a forested beach. The maximum difference in air temperature between two adjoining locations only varies between $0.2^{\circ} \mathrm{C}$ to $0.6^{\circ} \mathrm{C}$.

At night, the air temperature at the front location of the forested beach becomes colder because of the supply of fresh water from the land and the influence of ecological conditions including mangrove forests. Although the differences were not significant, the maximum temperature reached at the location in front of the settlement was earlier than at the location in front of the forested beach.In forested beach locations, the air temperature is also affected by the supply of fresh water from the mainland. The maximum gradient of air temperature above sea level, in front of the settlement is slightly higher than in front of a wooded beach. This shows that during the day, vertical variations in air temperature near the sea surface at the location in front of the settlement are more significant than those in front of forested beaches. Air-water thermal equilibrium is reached earlier in coastal waters in front of forested beaches than in front of settlements. This is allegedly due to the influence of environmental conditions such as the supply of fresh water, and mangrove forests. Air-sea thermal equilibrium only occurs around 1 to 1.5 hours. After 8:30 a.m., the sea water temperature becomes higher than the air temperature above it. The gradient changes direction (second thermal equilibrium) around 05:20 due to the influence of sunlight.

\section{Quantity of micro climate parameters: variable humidity} above the land surface

Table-1 shows the maximum humidity in residential areas ranging from $88.5 \%$ to $88.8 \%$. The maximum humidity on wooded beaches varies from $89.8 \%$ to $93.8 \%$. The maximum humidity in residential locations differs slightly from the maximum humidity on forested beaches. The maximum humidity at six locations occurs around 2:00 and is not significantly different. This moisture data is the result of analysis and modeling of measurement data at a position of $50 \mathrm{~cm}$ above the land surface. In the vertical direction, air humidity is not significantly different. This can be seen from the maximum gradient of low humidity for all locations. The minimum humidity in the six study sites did not differ significantly and only varied between $82.8 \%$ and $85.5 \%$. The minimum time for achieving humidity is almost the same for six locations, with variations from 11:35 to 11:54.

\section{Quantity of micro climate parameters: variable humidity} above the sea surface

Daily changes in air humidity above sea level at six measurement locations were not significantly different. The maximum air humidity in six locations varies between $89.8 \%$ to $90.4 \%$ and occurs at almost the same time around 00:50. The minimum humidity at six locations varies between $84.8 \%$ and $84 \%$ and there is no clear pattern between the location. The time of reaches of minimum humidity almost the same for six locations, it varies between 09:00 - 09:20. During that time, the sea water has not released much water vapor, while the concentration of water vapor in the air is reduced due to sun radiation.

\section{Daily pattern of changes of air temperature}


The air temperature and air humidity have a sinusoidal pattern due to solar radiation and the process of absorbing radiation energy which is then emitted as thermal energy.Figure-4 shows the daily dynamics of above-ground air temperature at three measurement locations, namely at the Para village settlement location (location code P1), Behongang village settlement location (location code B1), and forested beach of Kundaha (location code B2). The graph shows that at residential locations, the air temperature throughout the day is higher than the air temperature on forested beaches. The air temperature on forested beaches is more stable compared to the air temperature in residential areas. This difference shows that ecological conditions such as the presence of forests and mangrove forests, as well as shallow surface water and groundwater causes the air temperature in Kundaha to be lower than the air temperature in two residential locations.

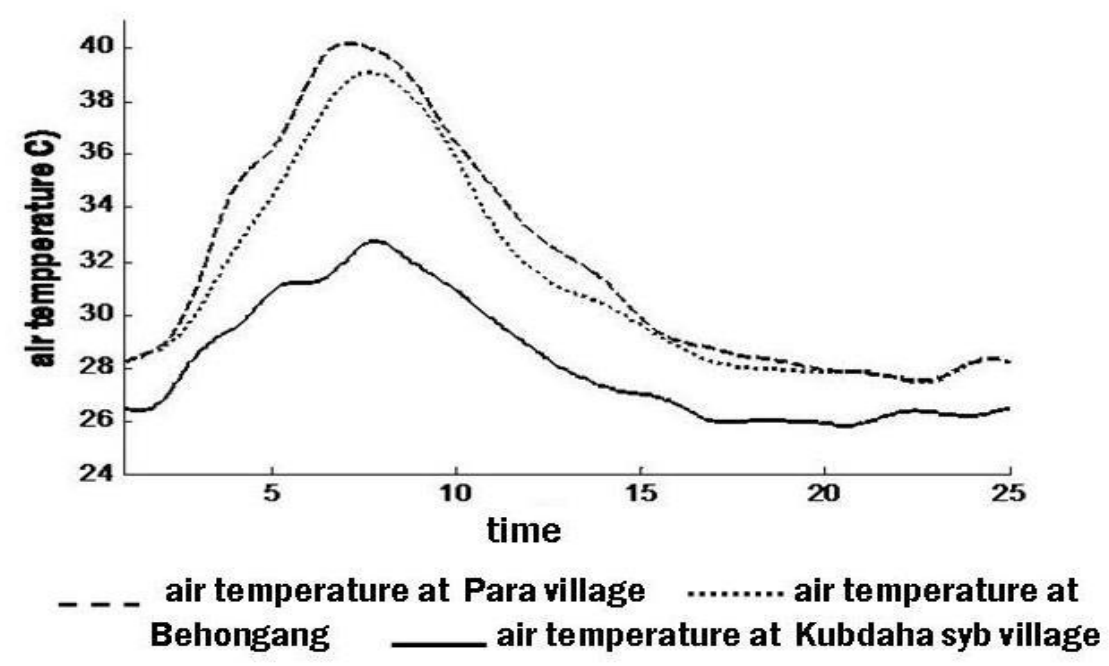

Figure-4, Variability of air temperature dynamic in small island

Micro-climate parameters data and the dynamics of daily changes of microclimate indicate that micro-climates on small islands vary greatly, mainly determined by ecosystem conditions, such as land cover, the presence of trees and mangrove trees, fresh water flow on the surface and underground water. Human activities such as cooking and other activities that produce heat also influence the increasingof air temperature at residential locations. Differences in ecological conditions that cause differences in the daily dynamics of microclimate, indicate the usefulness of microclimate data for characterizing and monitoring the condition of natural and environmental resources on small islands. The high spatial variation between residential areas and surrounding forests shows that deforestaion for settlement expansion will cause an increase in air temperature and subsequently will affect ecological conditions including animal life and environmental comfort. Micro-climate data in residential areas can be used as a reference for cultivating spices and vegetables in the yard, to divert forest reforms and the expansion of unproductive critical lands. The ecological conditions in important research locations must be respected especially for ensuring the availability of water in the dry season.

\section{CONCLUSION}

The microclimate on three islands in the Tatoareng subdistrict varies greatly, depending on ecological conditions such as the presence of forests and mangrove forests, land use for settlements. The parameters and daily dynamics of micro-climates can be used to characterize and monitor ecological changes in land and coastal waters on a small island.

\section{ACKNOWLEGMENT}

The author expresses his gratitude to the students of the Physics Department who have taken measurements, and to the fellow lecturers of the research team of the natural and environmental resources, for input in discussion of the research results. Acknowledgments are also conveyed to the 
Sangihe Island district government for research permission, as well as the people on the islands of Para, Mahengetang and Kahakitang who have prepared accommodation and sea transportation for the research team. This article is the output of a study funded by the Directorate General of Higher Education and the author expressed his gratitude for the research funding,

\section{REFERENCES}

[1] Bengen D. G., Tahir A., Wiryawan B., 2003 ImplementasidaerahperlindunganlautPulauSebesiKabu paten Lampung Selatan: tinjauanaspekkeberlanjutan, akuntabilitasdanreplikabilitas. ProyekPesisir PKSPLIPB, Bogor, pp

[2] Berger U, Rivera-Monroy V.H., Doyle Th.W., Dahdouh-Guebas F., Duke N.C, Fontalvo-Herazo M.L., Hildenbrandt H., Koedam N., Mehlig U., Piou C. and Twilley R.R., 2008. Advances and limitations of individual-based models to analyze and predict dynamics of mangrove forests. Aquatic Botany 89: 260-274

[3] Chatterjea K. 2014. Edge effects and exterior influences on Bukit Timah forest, Singapore, European Journal of Geography, 5(1): 8 - 31

[4] Chen J., Saunders S.C., Crow T.R., Naiman R.J., Brosofske K.D., Mroz G.D., Brookshire B.L., Franklin J.F. 1999. Microclimate in forest ecosystem and landscape ecology, BioScience, 49(4): 288-297

[5] Corbett J..Rambaldi G., Kyem P., Weiner D., Olson R., Muchemi J., McCall M., Chambers R. 2006. Mapping for change: the emergence of a new practice. Participatory Learning and Action 54:13-19

[6] de Paula M.D., Groeneveld J. and Huth A. 2016. The extent of edge effects in fragmented landscapes: Insights from satellite measurements of tree cover. Ecological Indicators 69:196-204

[7] De Lima B., Gilma N., Galvani E. 2013. Mangrove microclimate: acase study from Southeastern Brazil. Earth Interact., 17: 1-16.

[8] Godefroid S., Rucquoij S., Koedam N. 2006. Spatial variability of summer microclimates and plant species response along transects within clearcuts in a beech forest. Plant Ecol., 185:107-121

[9] Gradstein R. 2008. Influence of forest modification and climate change on epiphytic bryophyte diversity in the tropics. Paper presented at Annual Meeting of the Association for Tropical Biology and Conservation, Panamaribo 9-13 June, 2008
[10] Guinau M., Pallas R., Vilaplana J.M. 2005. A feasible methodology for landslide susceptibility assessment in developing countries: a casestudy of NW Nicaragua after Hurricane Mitch. Engineering Geology 80 (3-4): 316-327.

[11] Harper K.A, Macdonald S.E., Burton P.J., Chen J., Brosofske K.D., Saunders S.C, Euskirchen E.S., Roberts D., Jaiteh M.S., and Esseen P.A. 2005. Edge influence on forest structure and composition in fragmented landscapes. Conservation Biology, 19(3): $768-782$

[12] Heithecker T.D. and Halpern Ch.B. 2007. Edgerelated gradients in microclimate in forest aggregates following structural retention harvests in western Washington. Forest Ecology and Management, 248(3): 163-173

[13] Hennenberg K.J, Goetze D., Szarzynski J., Orthmann B., Reineking B., Steinke I., and Porembski S. 2008. Detection of seasonal variability in microclimatic borders and ecotones between forest and savanna. Basic and Applied Ecology. 9(3): 275 - 285.

[14] Magnago L.F.S, Rocha M.F., Meyer L., Martins S.V., Meira-Neto J.A.A. 2015. Microclimatic conditions at forest edges have significant impacts on vegetation structure in large Atlantic forest fragments. Biodivers. Conserv., 24: 2305-2318

[15] Medellu Ch. S., Soemarno, Marsoedi, and Berhimpon S. 2012. The influence of opening on the gradient and air temperature edge effects in mangrove forests. International Journal of Basic \& Applied Sciences IJBAS-IJENS. 12 (02): 53-57

[16] MedelluCh.S. 2012. Mathematical modeling of microclimate diurnal gradient in mangroveDisertation- Brawijaya, University, Malang, Indonesia.

[17] Medellu Ch. S. 2013. The area and index of diurnal dynamic of microclimate gradient as a mangrove environment interaction parameter. Journal of Natural Sciences Research. Vol 3, No 14, 2013. ISSN 2224-3186 (Paper) ISSN 2225-0921 (Online)-

[18] MedelluCh.S. and Tulandi D. 2018. Parameter: the area of microclimate gradient diurnal dynamic for characterization and monitoring of forest ecosystem and environment. International Journal of Environment, Agriculture and Biotechnology (IJEAB) Vol-3, Issue-3, May-June- 2018

[19] http://dx.doi.org/10.22161/ijeab/3.3.28 ISSN: 24561878 
[20] Mercer J., Dominey-Howes D., Kelman I., and Lloyd

K. 2007. The potential for combining indigenous and western knowledge in reducing vulnerability to environmental hazards in small island developing states. Environmental Hazards. 7: 245-256

[21] Newmark W.D. 2001. Tanzanian forest edge microclimatic gradients: dynamic patterns. Biotropica 33: $2-11$

[22] Pelling M., Uitto J.I. 2001. Small island developing states: natural disaster vulnerability and global change. Environmental Hazards 3 (2): 49-62.

[23] Pinto S.R.R., Mendes G., Santos A.M.M., Dantas M., Tabarelli M., and Melo F.P.L. 2010. Landscape attributes drive complex spatial microclimate configuration of Brazilian Atlantic forest fragments Tropical Conservation Science, 3(4): 389-402

[24] Pregiwati L.A., Wiryawan B., Baskoro M.S., Wisudo S.H., and Satria A., 2015. Linking indicators for ecosystem approach to fisheries management and management of marine protected area effectiveness in Anambas Island, Indonesia. International Journal of the Bioflux Society, 8(6): 1048 - 1063

[25] Rodolfo K.S., Siringan F.P. 2006. Global sea-level rise is recognised but flooding from anthropogenic land subsidence is ignored around Northern Manila Bay, Philippines. Disasters 30 (1): 118-139

[26] Manik, T., Rosadi, B., Pradana, O., \& Sanjaya, P. (2018). Engaging Farmers' community in climate change response and adaptation plans: in Sub-district Sedayu, Lampung Province, Indonesia. International Journal of Rural Development, Environment and Health Research, 2(1), 18-25. doi: 10.22161/ijreh.2.1.3

[27] Van Aalst M.K. 2006. The impacts of climate change on the risk of natural disasters. Disasters 30 (1): 5-18.

[28] White A., Alino P., Meneses A. 2006 Creating and managing marine rotected areas in the Philipines, Cebu City, Philipines: Fisheries improved sustainable harvest project.Coastal Conservation and Education Foundation, Inc. and University of Philipines Marine Science Institute, viiit $83 \mathrm{p}$.

[29] Zulkiflee A.L., Blackburn G.A. 2010. The effects of gap size on some microclimate variables during late summer and autumn in a temperate broadleaved deciduous forest. International Journal of Biometeorology, 54: 119-129 